\title{
First, Do No Harm: Critical Appraisal of Protein Restriction for Diabetic Kidney Disease
}

\author{
Satoru Yamada \\ Diabetes Center, Kitasato Institute Hospital, Kitasato University, 5-9-1 Shirokane, Minato-ku, \\ Tokyo 108-8642, Japan; yamada-s@insti.kitasato-u.ac.jp; Tel.: +81-33444-6161; Fax: +81-3-3448-0553
}

check for updates

Citation: Yamada, S. First, Do No Harm: Critical Appraisal of Protein Restriction for Diabetic Kidney Disease. Diabetology 2021, 2, 51-64. https://doi.org/10.3390/ diabetology2020005

Academic Editor: Keiichiro Matoba

Received: 5 February 2021

Accepted: 16 April 2021

Published: 22 April 2021

Publisher's Note: MDPI stays neutral with regard to jurisdictional claims in published maps and institutional affiliations.

Copyright: (C) 2021 by the author. Licensee MDPI, Basel, Switzerland. This article is an open access article distributed under the terms and conditions of the Creative Commons Attribution (CC BY) license (https:// creativecommons.org/licenses/by/ $4.0 /)$.

\begin{abstract}
Low-protein diets have been recommended as diet therapy for the management of chronic kidney disease; however, its effect on chronic kidney disease has not been scientifically proven. Although several studies have reported significantly more favorable results with low-protein diet than with normal-protein diet, the renal protective effects of low-protein diets are still unclear in diabetic patients with chronic kidney disease. Moreover, some studies have reported that extremely low-protein diets may increase the risk of mortality. Thus, this paper describes the effectiveness and safety of low-protein diets for patients with diabetic kidney disease by reviewing the historical background of different low-protein diets that were critically examined in several studies.
\end{abstract}

Keywords: protein restriction; diabetic kidney disease; eGFR; hyperfiltration theory

\section{Introduction}

Low-protein diets are typically recommended as diet therapy for the management of chronic kidney disease (CKD) regardless of its type (i.e., diabetic kidney disease (DKD) or non-diabetic chronic kidney disease (non-DM-CKD)). A review article by Kalantar-Zadeh et al. [1] published in the New England Journal of Medicine in 2017 and the clinical practice recommendation for DKD by the 2020 Kidney Disease: Improving Global Outcomes (KDIGO) (KDIGO 2020) [2] both recommend low-protein diets for CKD. Kalantar-Zadeh et al. [1] stated that protein reduction should be prioritized over other nutrients, such as sodium, potassium, and phosphorus. However, its effects on CKD are yet to be proven scientifically as Kalantar-Zadeh et al. [1] stated, "It is possible, though not yet unequivocally proved, that nutritional interventions slow disease progression," and the KDIGO 2020 [2] stated that "the certainty of the evidence" is "low" or "very low." In fact, the American Diabetes Association [3] recommended the following nutrition recommendations until 2008: (1) diet with $0.8-1.0 \mathrm{~g} / \mathrm{kg}$ protein for diabetic patients with microalbuminuria, and (2) $0.8 \mathrm{~g} / \mathrm{kg}$ protein for diabetic patients with macroalbuminuria. However, this recommendation was retracted in 2013 as these low-protein diets did not have renal protective effects. Since then, the same level of protein intake has been recommended for diabetic patients with DKD as that for healthy adults (1.0-1.5 g/ kg) [3-5]. Given the uncertainties involved with low-protein diets for diabetic patients with CKD, this review discusses the effectiveness and safety of low-protein diets for DKD. This study reviewed the historical background of different low-protein diets, which were critically examined in several studies that were used by Kalantar-Zadeh et al. [1] and the KDIGO 2020 [2].

\section{Historical Background of Low-Protein Diet Recommendations}

Low-protein diets were first recommended for patients with kidney disease by Addis [6], specifically for glomerulonephritis, because the urinary excretion of urea loads the kidneys. Thereafter, Brenner et al. [7] reported that excessive protein intake causes an increase in both glomerular filtration and glomerular pressure, and recommended lowprotein diets for patients with age-related renal dysfunction and DKD. Furthermore, partial loss of glomerular function irrespective of the cause leads to compensatory hyperfiltration 
and subsequent increased injury of the remaining glomeruli. This was referred to as the "hyperfiltration theory." Researchers, since then, considered that low-protein diets and renin-angiotensin system (RAS) inhibition were effective in protecting renal function [8]. It can be said that the glomerular hyperfiltration theory per se has been proven by the renal protective effects of sodium-glucose cotransporter-2 (SGLT2) inhibitors, which occur potentially via tubuloglomerular feedback in chronic kidney disease [9-11]. SGLT2 inhibitors have been found to decrease the estimated glomerular filtration rate (eGFR) at an early stage; however, the rate of decrease lowers subsequently. As compared to the control group, the eGFR of patients receiving SGLT2 inhibitors was maintained at a higher level after administering these drugs for approximately one year. These findings suggest that SGLT2 inhibitors help reduce glomerular hypertension and hyperfiltration. In fact, one hypothesis stated that high-protein diets might lead to a decrease in the renal protective effects of SGLT2 inhibitors [12]. However, hyperfiltration attributed to high-protein or normal-protein diets is yet to be verified. The Modification of Diet in Renal Disease (MDRD) study (Study 1) found that eGFR changes in the low-protein diet group were similar to those in patients receiving SGLT2 inhibitors [13]. This is potential evidence that high-protein intake leads to hyperfiltration, which is used as a rationale for the significance of low-protein diets [1]. In contrast, the Northern Italian Cooperative Study reported contradictory results [14]. The study found that the remaining renal function in a subgroup, which included patients with the highest baseline blood creatinine levels, decreased rapidly at an early stage as the patients received normal-protein diets. Similarly, the rate of decrease was slower in this group at a later stage than in the group receiving low-protein diets. That is, the association between a normal protein intake level and hyperfiltration has not been verified. Meanwhile, a follow-up study of the MDRD study (Study 1) found that the progression of renal dysfunction was faster in the low-protein diet group at six years or later, although no statistically significant difference was observed [15]. Thus, the hypothesis that protein intake leads to hyperfiltration could not be verified by this study (Study 1). Therefore, further research is needed to evaluate whether normal-protein diets with a protein intake of 1.0-1.5 g/ kg cause glomerular hyperfiltration in injured kidneys [16]; it could not be determined whether such protein diets lead to hyperfiltration before data are obtained, indicating that low-protein diets are effective in protecting the kidneys of patients with CKD. Hostetter et al. [17] used rats with one kidney removed and those with one kidney and one-third of the contralateral kidney removed, and histologically found that high-protein diets with protein accounting for $40 \%$ of the total energy intake (all casein) led to nephrosclerosis. Consequently, low-protein diets were recommended; however, their findings did not go beyond the experimental level where high-protein diets were quantitatively and qualitatively examined in experimental disease conditions. For a protein diet accounting for $40 \%$ of the total energy intake, a $50 \mathrm{~kg}$ woman with a 2000 kcal daily energy intake would need to eat $4.0 \mathrm{~g} / \mathrm{kg}$ of protein. Meanwhile, young men attempting to increase their musculature typically consume up to $3.0 \mathrm{~g} / \mathrm{kg}$ of protein [18], which accounts for only $30 \%$ of the total energy intake [19]. The hyperfiltration theory proposed by Brenner et al. $[7,8]$ has not been supported by any clinical study on normal protein intake in CKD patients. Findings from animal experiments (preclinical studies) should not be directly applied to any human clinical decision making. The decision of clinician should always be determined based on the results of clinical studies. Hence, this review examined the clinical studies that were used as rationales for recommendations by Kalantar-Zadeh et al. [1] and the KDIGO 2020 [2].

\section{Effectiveness and Safety of Low-Protein Diets}

\subsection{Effectiveness of Low-Protein Diets in 18 Studies Cited by Kalantar-Zadeh et al.}

Kalantar-Zadeh et al. [1] recommended low-protein diets (Table 1). In their article, they emphasized their preference for low-protein diet over diet recommendations on sodium, potassium, phosphorus, calcium, fibers, alkali, plant-based foods, energy, and fats. Low-protein diets with a protein intake of $<1.0 \mathrm{~g} / \mathrm{kg}$ are recommended for people 
without CKD but with risk for CKD, such as those with diabetes or hypertension. Although Kalantar-Zadeh et al.'s study [1] is not a review on DKD, further verification is necessary for its low-protein diet recommendation for diabetic patients without CKD. In particular, it is necessary to validate whether there is any rationale for restricting normal-protein diets $(1.0-1.5 \mathrm{~g} / \mathrm{kg})$ in all diabetic patients. Kalantar-Zadeh et al. Reference [1] cited 18 papers as references. These papers were selected because they reported on controlled trials consisting of greater than 30 participants that have examined the effects of low-protein or very low-protein diets on various outcome measures in patients with CKD (Table 2).

Table 1. Recommended daily protein intake in a review article by Kalantar-Zadeh et al.'s paper.

\begin{tabular}{|c|c|c|c|c|c|c|}
\hline CKD Stage & $\begin{array}{c}\text { Normal Kidney } \\
\text { Function with } \\
\text { Increased CKD } \\
\text { Risk }\end{array}$ & $\begin{array}{c}\text { Mild-to-Moderate } \\
\text { CKD }\end{array}$ & Advanced CKD & \multirow{2}{*}{$\begin{array}{c}\text { Transition to } \\
\text { Dialysis }\end{array}$} & \multirow{2}{*}{$\begin{array}{l}\text { Ongoing } \\
\text { Dialysis }\end{array}$} & \multirow{2}{*}{$\begin{array}{l}\text { Any Stage } \\
\text { with PEW }\end{array}$} \\
\hline $\begin{array}{c}\text { CKD stage } \\
\left(\mathrm{mL} / \mathrm{min} / 1.73 \mathrm{~m}^{2}\right)\end{array}$ & $\begin{array}{l}\text { eGFR } \geq 60 \text { with } \\
\text { CKD risk }\end{array}$ & $60>$ eGFR $\geq 30$ & $\begin{array}{c}30>\mathrm{eGFR} \text { or } \\
\text { proteinuria } \\
>0.3 \mathrm{~g} / \text { day }\end{array}$ & & & \\
\hline $\begin{array}{l}\text { Daily protein } \\
\text { intake }(\mathrm{g} / \mathrm{kg})\end{array}$ & $<1.0$ & $<1.0$ & $\begin{array}{l}0.6-0.8 \text { including } \\
50 \% \mathrm{HBV} \text {, or }<0.6 \\
\text { with EAA or KA }\end{array}$ & $\begin{array}{c}0.6-0.8 \text { on } \\
\text { non-dialysis } \\
\text { days and } \\
>1.0 \text { on } \\
\text { dialysis days }\end{array}$ & $1.2-1.4$ & $>1.5$ \\
\hline $\begin{array}{c}\text { Other } \\
\text { considerations }\end{array}$ & $\begin{array}{c}\text { Increased } \\
\text { proportion of } \\
\text { plant-based } \\
\text { protein }\end{array}$ & $\begin{array}{c}\text { Consider } 0.6-0.8 \text { if } \\
\text { eGFR }<45\end{array}$ & & & & \\
\hline
\end{tabular}

CKD, chronic kidney disease; PEW, protein-energy wasting; HBV, high biologic value; EAA, essential amino acids; KA, ketoacids. Reprinted with permission from ref. [1]. Copyright 2017 Massachusetts Medical Society.

Table 2. Abstracts of 18 papers from Kalantar-Zadeh et al.'s paper.

\begin{tabular}{|c|c|c|c|c|c|c|}
\hline $\begin{array}{c}\text { First } \\
\text { Author }\end{array}$ & $\begin{array}{l}\text { Reference } \\
\text { Numbers }\end{array}$ & Patients & $\begin{array}{l}\text { Intervention } \\
\text { (Daily Protein } \\
\text { Intake) }\end{array}$ & Comparison & Outcome & Results \\
\hline Rosman & [20] & $\begin{array}{c}\text { Ccr } \\
10-60 \mathrm{~mL} / \mathrm{min} \\
n=228 \\
\text { non-DM } \\
C \mathrm{cr}\end{array}$ & $\begin{array}{c}0.6 \mathrm{~g} \text { (CKD3), } \\
0.4 \mathrm{~g} \text { (CKD4-5) }\end{array}$ & Usual Protein & $\begin{array}{c}\text { SCr10\% elevation at } \\
2 \text { years }\end{array}$ & $\begin{array}{l}\bigcirc 40 \% \text { vs. } 75 \% \text { (CKD } 3) \\
\bigcirc 50 \% \text { vs. } 97 \% \text { (CKD 4-5) }\end{array}$ \\
\hline Rosman & [21] & $\begin{array}{c}10-60 \mathrm{~mL} / \mathrm{min} \\
n=248 \\
\text { non-DM }\end{array}$ & $\begin{array}{c}0.6 \mathrm{~g} \text { (CKD3), } \\
0.4 \mathrm{~g} \text { (CKD4-5) }\end{array}$ & Usual Protein & Ccr decline & $\begin{array}{c}\mathbf{\Delta}-0.28 \text { vs. }-0.31 \text { (CKD 3) } \\
\bigcirc-0.16 \text { vs. }-0.20(\text { CKD } 4-5)\end{array}$ \\
\hline Ihle & [22] & $\begin{array}{c}\mathrm{Cr} \\
4-11 \mathrm{~mL} / \mathrm{min} \\
\mathrm{CKD}, n=64 \\
\text { non-DM }\end{array}$ & $0.4 \mathrm{~g}$ & Usual Protein & ESRD & 2/31 vs. $9 / 33$ \\
\hline Lindenau & [23] & $\begin{array}{c}\mathrm{Ccr}< \\
15 \mathrm{~mL} / \mathrm{min}, \\
n=40 \\
\text { no description } \\
\text { of primary } \\
\text { renal disease }\end{array}$ & $0.4 \mathrm{~g}+$ keto acids & $0.6 \mathrm{~g}$ & Bone biopsy & $\begin{array}{l}\text { keto acids reduce bone } \\
\text { fibrotic change }\end{array}$ \\
\hline Williams & [24] & $\begin{array}{c}\mathrm{SCr}>1.70 \text { (Male), } \\
>1.47 \text { (Female) } \\
\mathrm{mg} / \mathrm{dL}, n=95 \\
12 / 95(12.6 \%) \\
\text { were DKD }\end{array}$ & $0.6 \mathrm{~g}$ & $0.8 \mathrm{~g}$ & Cor decline & $\Delta-0.56$ vs. -0.69 \\
\hline
\end{tabular}


Table 2. Cont

\begin{tabular}{|c|c|c|c|c|c|c|}
\hline $\begin{array}{l}\text { First } \\
\text { Author }\end{array}$ & $\begin{array}{l}\text { Reference } \\
\text { Numbers }\end{array}$ & Patients & $\begin{array}{l}\text { Intervention } \\
\text { (Daily Protein } \\
\text { Intake) }\end{array}$ & Comparison & Outcome & Results \\
\hline Locatelli & [14] & $\begin{array}{c}\text { CKD 3-5, } \\
n=456 \\
\text { non-DM }\end{array}$ & $0.6 \mathrm{~g}$ & $1.0 \mathrm{~g}$ & SCr doubling or HD & $\Delta 27 / 226$ vs. $42 / 230$ \\
\hline Klahr & [13] & $\begin{array}{c}25-55 \mathrm{~mL} / \mathrm{min} / \\
1.73 \mathrm{~m}^{2}, n=585 \\
\text { GFR } \\
13-24 \mathrm{~mL} / \mathrm{min} / \\
1.73 \mathrm{~m}^{2}, n=255 \\
3 \% \text { was DKD }\end{array}$ & $\begin{array}{c}0.58 \mathrm{~g} \text { in study } 1 \\
0.28 \mathrm{~g}+\text { keto acid } \\
\text { in study } 2\end{array}$ & $\begin{array}{c}1.3 \mathrm{~g} \text { study } 1 \\
0.58 \mathrm{~g} \text { study } 2\end{array}$ & GFR decline & $\begin{array}{l}-3.6 \text { vs. }-4.0 \\
-4.4 \text { vs. }-3.6\end{array}$ \\
\hline $\begin{array}{l}\text { Montes- } \\
\text { Delgado }\end{array}$ & [25] & $\begin{array}{c}\text { CRF, } n=33 \\
\text { 9/33 }(27.3 \%) \\
\text { were DKD } \\
\text { GFR < }\end{array}$ & $\begin{array}{l}0.6 \mathrm{~g}+\text { high } \\
\text { energy }\end{array}$ & $0.6 \mathrm{~g}$ & Ccr decline & $11 \rightarrow 10.7$ vs. $18.3 \rightarrow 13.8$ \\
\hline Malvy & [26] & $\begin{array}{l}20 \mathrm{~mL} / \mathrm{min} / \\
1.73 \mathrm{~m}^{2}, n=50 \\
\text { non-DM }\end{array}$ & $0.3 \mathrm{~g}+$ keto acid & $0.65 \mathrm{~g}$ & $\begin{array}{c}\mathrm{GFR}<5 \\
\mathrm{~mL} / \mathrm{min} / 1.73 \mathrm{~m}^{2}\end{array}$ & A $100 \%$ vs. $100 \%$ \\
\hline Teplan & [27] & $\begin{array}{c}\text { Ccr } \\
22-36 \mathrm{~mL} / \mathrm{min} \\
n=105 \\
\text { non-DM }\end{array}$ & $\begin{array}{l}0.6 \mathrm{~g}+\mathrm{EPO}+ \\
\text { keto acid } \\
0.6 \mathrm{~g}+\mathrm{EPO}\end{array}$ & $0.6 \mathrm{~g}$ & Cor decline & $\begin{array}{c}\mathrm{O}-0.672 \text { (EPO + keto acid) vs. } \\
-2.124 \text { (control) } \\
\Delta-1.512(\text { EPO) vs. }-2.124 \\
\text { (control) }\end{array}$ \\
\hline Prakash & [28] & $\begin{array}{c}\text { Ccr } 20-50 \\
n=34 \\
20 / 34(58.8 \%) \\
\text { were DKD }\end{array}$ & $0.3 \mathrm{~g}+$ keto acids & $0.6 \mathrm{~g}+$ placebo & eGFR decline & n.a. $28.1 \rightarrow 27.6$ vs. $28.6 \rightarrow 22.5$ \\
\hline Brunori & [29] & $\begin{array}{l}\text { CKD } 5, n=56 \\
\text { non-DM }\end{array}$ & $0.3 \mathrm{~g}+$ keto acids & $1.2 \mathrm{~g}+$ HD start & Mortality & A $12.7 \%$ vs. $16.3 \%$ \\
\hline Mircescu & [30] & $\begin{array}{c}\text { CKD 4-5, } \\
n=53 \\
\text { non-DM }\end{array}$ & $0.3 \mathrm{~g}+$ keto acids & $0.6 \mathrm{~g}$ & Urea & $\begin{array}{c}\Delta \text { Urea nitrogen } \\
73.3 \rightarrow 56.5 \text { vs. } 63.0 \rightarrow 67.2\end{array}$ \\
\hline Cianciaruso & {$[31]^{*}$} & $\begin{array}{c}\text { CKD } 4-5 \\
n=423 \\
12 \% \text { was DKD }\end{array}$ & $0.55 \mathrm{~g}$ & $0.80 \mathrm{~g}$ & $\begin{array}{l}\text { PEM, HD, GFR } \\
\text { decline }\end{array}$ & $\begin{array}{l}\text { \ PEM2 vs. } 1, \text { HD41 vs. } 42, \\
\text { GFR }-0.19 \text { vs. }-0.18\end{array}$ \\
\hline Di Lorio & [32] & $\begin{array}{c}\text { CKD moderate- } \\
\text { advanced, } \\
n=32 \\
20 / 32(62.5 \%) \\
\text { were DKD }\end{array}$ & $0.3 \mathrm{~g}+$ keto acids & Low protein & Proteinuria & $58 \%$ reduce \\
\hline Jiang & {$[33]$ * } & $\begin{array}{l}\text { PD, } n=34 \\
2 / 34(5.9 \%) \\
\text { were DKD }\end{array}$ & $\begin{array}{l}0.6-0.8 \mathrm{~g} / \mathrm{kg} \text { IBW } \\
\text { With or without } \\
\text { Keto acids }\end{array}$ & $1.0-1.2$ & GFR decline & 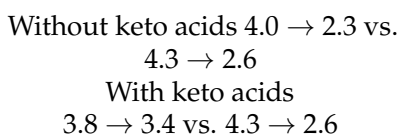 \\
\hline Jiang & [34] & $\begin{array}{l}\mathrm{PD}, n=60 \\
3 / 60(5.0 \%) \\
\text { were DKD }\end{array}$ & $\begin{array}{l}0.6-0.8 \mathrm{~g} / \mathrm{kg} \text { IBW } \\
\text { With or without } \\
\text { Keto acids }\end{array}$ & $1.0-1.2$ & Peritoneal function & $\begin{array}{c}\boldsymbol{\Delta} \text { without keto acids } \\
\bigcirc \text { with keto acids }\end{array}$ \\
\hline Garneata & [35] & $\begin{array}{l}\text { CKD 4-5, } \\
n=207 \\
\text { non-DM }\end{array}$ & $\begin{array}{l}0.3-0.4 \mathrm{~g}+\text { keto } \\
\text { acids + vegetarian }\end{array}$ & $0.6 \mathrm{~g}$ & $\begin{array}{l}\text { HD start or GFR } \\
50 \% \text { loss }\end{array}$ & $13 \%$ vs. $42 \%$ \\
\hline
\end{tabular}

* The two papers were originally proceedings of a scientific meeting. In this review, the author selected articles from other medical journals whose titles were similar. Abbreviations: Ccr, creatinine clearance; $\mathrm{Cr}$, creatinine; SCr, serum creatinine; GFR, glomerular filtration rate; $\mathrm{CKD}$, chronic kidney disease; EPO, erythropoietin; PD, peritoneal dialysis; ESRD, end-stage renal disease; HD, hemodialysis; CRF, chronic renal failure; n.a., not available; IBW, ideal body weight. $\bigcirc$ indicates that intervention was statistically superior to control. $\Delta$ indicates that there was not statistically significant difference between intervention and control. Reprinted with permission from ref. [1]. Copyright 2017 Massachusetts Medical Society.

Among the 18 studies [13,14,20-35], eight had significantly more favorable results in the intervention group (low-protein diet) than in the control group (normal-protein diet) in terms of study outcomes. However, these studies did not necessarily examine the renal protective effects of low-protein diets. For example, the amount of protein intake was the same between the intervention and control groups, as reported by Montes-Delgado et al. [25] and Teplan et al. [27], who examined the renal protective effects of high-energy diets and supplements such as erythropoietin (EPO) and keto acids. Lindenau et al.'s study [23] did not report on renal function; however, it provided bone biopsy results. In 
recent years, there has been an increase in the use of eGFR changes as a surrogate marker when examining outcomes in studies on the kidneys [36,37]. Table 3 presents ten articles that reported changes in renal function as outcomes in genuine intervention studies of low-protein diets for patients with predialysis renal failure.

Table 3. Abstracts of ten articles selected from Kalantar-Zadeh et al.'s paper that evaluated the renal protective effect of protein restriction intervention.

\begin{tabular}{|c|c|c|c|c|c|c|c|}
\hline $\begin{array}{l}\text { First Author } \\
\text { (Year } \\
\text { Published) }\end{array}$ & $\begin{array}{l}\text { Reference } \\
\text { Numbers }\end{array}$ & Patients & $\begin{array}{l}\text { Intervention (I) } \\
\text { (Daily Protein } \\
\text { Intake) }\end{array}$ & Comparison (C) & $\begin{array}{c}\text { GFR }(\mathrm{mL} / \mathrm{min} / 1.73 \\
\left.\mathrm{m}^{2}\right) \text { or Ccr } \\
(\mathrm{mL} / \mathrm{min}) \text { Decline } \\
\text { per Year in I }\end{array}$ & $\begin{array}{c}\text { GFR }(\mathrm{mL} / \mathrm{min} / 1.73 \\
\left.\mathrm{m}^{2}\right) \text { or Ccr } \\
(\mathrm{mL} / \mathrm{min}) \text { Decline } \\
\text { per Year in C }\end{array}$ & $\begin{array}{c}\text { Statistical } \\
\text { Significance } \\
\text { between Groups }\end{array}$ \\
\hline $\begin{array}{c}\text { Rosman } \\
(1989)\end{array}$ & {$[21]$} & $\begin{array}{c}\text { Ccr } 10-60 \mathrm{~mL} / \mathrm{min} \\
n=248 \\
\text { non-DM }\end{array}$ & $\begin{array}{c}0.6 \mathrm{~g}(\text { (CKD 3), } \\
0.4 \mathrm{~g} \text { (CKD 4-5) }\end{array}$ & Usual Protein & $\begin{array}{c}\mathrm{Ccr}-3.36(\mathrm{CKD} 3) \\
\mathrm{Ccr}-1.92(\mathrm{CKD} \\
4-5)\end{array}$ & $\begin{array}{c}\mathrm{Ccr}-3.72(\mathrm{CKD} 3) \\
\mathrm{Ccr}-2.40(\mathrm{CKD} \\
4-5)\end{array}$ & $\begin{array}{c}\text { n.s. (CKD 3) } \\
\bigcirc(\text { (CKD 4) }\end{array}$ \\
\hline $\begin{array}{l}\text { Ihle } \\
(1989)\end{array}$ & [22] & $\begin{array}{c}\mathrm{SCr} 4-11 \mathrm{mg} / \mathrm{dL} \\
n=64 \\
\text { non-DM }\end{array}$ & $0.4 \mathrm{~g}$ & Usual Protein & $\mathrm{Ccr}-1.8 \mathrm{~mL} / \mathrm{min}$ & $\mathrm{Ccr}-6.0 \mathrm{~mL} / \mathrm{min}$ & $\bigcirc$ \\
\hline $\begin{array}{l}\text { Williams } \\
\text { (1991) }\end{array}$ & [24] & $\begin{array}{c}\mathrm{SCr}>1.70 \text { (Male) } \\
>1.47 \text { (Female) } \\
\mathrm{mg} / \mathrm{dL}, n=95 \\
12 / 95(12.6 \%) \text { were } \\
\text { DKD }\end{array}$ & $0.6 \mathrm{~g}$ & $0.8 \mathrm{~g}$ & $\mathrm{Ccr}-6.72$ & $\mathrm{Ccr}-8.28$ & n.s. \\
\hline $\begin{array}{l}\text { Locatelli } \\
\text { (1991) }\end{array}$ & [14] & $\begin{array}{c}\text { CKD 3-5, } n=456 \\
\text { non-DM } \\
\text { GFR 25-55 }\end{array}$ & $0.6 \mathrm{~g}$ & $1.0 \mathrm{~g}$ & $\mathrm{Ccr}-1.8$ & Ccr-1.0 & n.s. \\
\hline $\begin{array}{l}\text { Klahr } \\
(1994)\end{array}$ & [13] & $\begin{array}{c}\mathrm{mL} / \min / 1.73 \mathrm{~m}^{2} \\
n=585 \\
\text { GFR } 13-24 \\
\mathrm{~mL} / \min / 1.73 \mathrm{~m}^{2} \\
n=255 \\
\text { 3\% was DKD }\end{array}$ & $\begin{array}{c}0.58 \text { g study } 1 \\
0.28 \text { g + keto acid } \\
\text { study } 2\end{array}$ & $\begin{array}{c}1.3 \mathrm{~g} \text { study } 1 \\
0.58 \mathrm{~g} \text { study } 2\end{array}$ & $\begin{array}{l}-3.6 \\
-3.6\end{array}$ & $\begin{array}{l}-4.0 \\
-4.4\end{array}$ & $\begin{array}{l}\text { n.s. } \\
\text { n.s. }\end{array}$ \\
\hline $\begin{array}{l}\text { Malvy } \\
(1999)\end{array}$ & [26] & $\begin{array}{c}\text { GFR }<20 \\
n=50 \\
\text { non-DM }\end{array}$ & $0.3 \mathrm{~g}+$ keto acid & $0.65 \mathrm{~g}$ & -3.26 & -2.89 & n.s. \\
\hline $\begin{array}{l}\text { Prakash } \\
(2004)\end{array}$ & [28] & $\begin{array}{c}\text { Ccr } 20-50 \mathrm{~mL} / \mathrm{min}, \\
n=34 \\
20 / 34(58.8 \%) \text { were } \\
\text { DKD }\end{array}$ & $0.3 \mathrm{~g}+$ keto acid & $0.6 \mathrm{~g}+$ placebo & -2.0 & -8.1 & $\bigcirc$ \\
\hline $\begin{array}{l}\text { Mircescu } \\
(2007)\end{array}$ & [30] & $\begin{array}{c}\text { CKD 4-5, } \\
n=53 \\
\text { non-DM }\end{array}$ & $0.3 \mathrm{~g}+$ keto acids & $0.6 \mathrm{~g}$ & -3.1 & -4.9 & n.a. \\
\hline $\begin{array}{c}\text { Cianciaruso } \\
\text { (2009) }\end{array}$ & [31] & $\begin{array}{c}\text { CKD } 4-5, n=423 \\
12 \% \text { was DKD }\end{array}$ & $0.55 \mathrm{~g}$ & $0.80 \mathrm{~g}$ & -2.28 & -2.16 & n.s. \\
\hline $\begin{array}{c}\text { Garneata } \\
(2016)\end{array}$ & [35] & $\begin{array}{c}\text { CKD 4-5, } n=207 \\
\text { non-DM }\end{array}$ & $\begin{array}{c}0.3-0.4 \mathrm{~g}+\text { keto } \\
\text { acids + vegetarian }\end{array}$ & $0.6 \mathrm{~g}$ & -2.9 & -7.1 & 0 \\
\hline
\end{tabular}

Abbreviations: Ccr, creatinine clearance; $\mathrm{Cr}$, creatinine; $\mathrm{SCr}$, serum creatinine; GFR, glomerular filtration rate; CKD, chronic kidney disease; EPO, erythropoietin; PD, peritoneal dialysis; ESRD, end-stage renal disease; HD, hemodialysis; CRF, chronic renal failure; n.a., not available; n.s., not significant. $\bigcirc$ indicates that intervention was statistically superior to control. Adapted with permission from ref. [1]. Copyright 2017 Massachusetts Medical Society.

None of these studies used a protein intake of $<1.0 \mathrm{~g} / \mathrm{kg}$ or $0.6-0.8 \mathrm{~g} / \mathrm{kg}$, which was recommended by Kalantar-Zadeh et al. [1]. In addition, four of the 10 studies (one of them only examined patients with CKD 4-5) reported that low-protein diets protected renal function (Table 3). All four studies used extremely low-protein diets with a protein intake of $0.3 \mathrm{~g} / \mathrm{kg}$ or $0.4 \mathrm{~g} / \mathrm{kg}$. However, in three of the four studies [22,28,35], the eGFR in the control group decreased by $5 \mathrm{~mL} / \mathrm{min} / 1.73 \mathrm{~m}^{2}$ annually. Patients experiencing a decrease in the eGFR at a rate faster than $5 \mathrm{~mL} / \mathrm{min} / 1.73 \mathrm{~m}^{2}$ annually were referred to as rapid decliners or rapid progressors, who have a special clinical condition [38]. It would be difficult to generalize data from a study that solely examines rapid decliners. The remaining study [21] observed significant differences in the rate of decrease in Ccr levels in patients with CKD 4-5. However, it is intriguing that the rate of decrease in Ccr levels in patients with CKD 4-5 in the normal-protein diet group (control group) was slower than that in patients with CKD 3 in the low-protein diet group. The results of the study completely overturned the hyperfiltration hypothesis. Hence, the articles cited by Kalantar-Zadeh et al. [1] cannot be used as a rationale for recommending low-protein diets, regardless of the following recommended amount of intake: $<1.0 \mathrm{~g} / \mathrm{kg}, 0.6-0.8 \mathrm{~g} / \mathrm{kg}$, or $0.3-0.4 \mathrm{~g} / \mathrm{kg}$. 


\subsection{Effectiveness of Low-Protein Diets in Nine Studies Cited in the KDIGO 2020}

The KDIGO 2020 recommends low-protein diets with $0.8 \mathrm{~g} / \mathrm{kg}$ and $1.0-1.2 \mathrm{~g} / \mathrm{kg}$ of protein for diabetic patients with CKD and dialysis patients, respectively [5]. This systematic review consisting of 11 articles was used as a rationale for these recommendations. However, the certainties of the evidence for all-cause mortality and end-stage kidney disease were low, and those for doubling of serum creatinine levels and changes in eGFR were very low. The KDIGO 2020 report stated in its Table S12, "we are uncertain whether low-protein diet improves or worsens change in eGFR." It is intriguing that the article recommended low-protein diets although worsening of the eGFR could not be ruled out. For example, a systematic review of all-cause mortality included only two studies (this cannot be considered a systematic review). Based on the review, a decrease in mortality by 21 per 1000 people can be expected in low-protein diet groups during a mean follow-up period of 4.5 years $[5,39,40]$. A summary of the results of the abovementioned studies is presented in Table 4, which included the following causes of death: myocardial infarction, heart failure, and sepsis. However, the basis of the KDIGO Diabetes Work Group's claims remains questionable. Even if there were statistically significant differences, it can be concluded that low-protein diets are not effective in reducing all-cause mortality. Meanwhile, the KDIGO Diabetes Work Group examined changes in eGFR from eight studies [39,41-47], which are summarized in Table 5. Among the eight studies, only two observed significant differences in eGFR changes [41,42]. Both the studies reported that low-protein diets were effective for patients with type 1 diabetes. In these studies, patients with type 1 diabetes received interventions consisting of low-protein diets with a protein intake of $0.6 \mathrm{~g} / \mathrm{kg}$, and rapid progression was observed in the control group with a decrease in the eGFR at an annual rate of $12.7-25 \mathrm{~mL} / \mathrm{min} / 1.73 \mathrm{~m}^{2}$. However, the annual rates of eGFR decrease are $2.7 \mathrm{~mL} / \mathrm{min} / 1.73 \mathrm{~m}^{2}$ in patients with CKD stage G3 $\left(30 \mathrm{~mL} / \mathrm{min} / 1.73 \mathrm{~m}^{2}<\mathrm{eGFR}<60 \mathrm{~mL} / \mathrm{min} / 1.73 \mathrm{~m}^{2}\right)$ type 1 diabetes and $3.7 \mathrm{~mL} / \mathrm{min} /$ $1.73 \mathrm{~m}^{2}$ in those with CKD stage G4 $\left(15 \mathrm{~mL} / \mathrm{min} / 1.73 \mathrm{~m}^{2}<\right.$ eGFR $\left.<30 \mathrm{~mL} / \mathrm{min} / 1.73 \mathrm{~m}^{2}\right)$ type 1 diabetes [48]. Studies that discuss extreme conditions in which the eGFR decreases at an annual rate of $12.7-25 \mathrm{~mL} / \mathrm{min} / 1.73 \mathrm{~m}^{2}$ cannot be used as references for everyday practice. There are no rationales for low-protein diets with a protein intake of $0.8 \mathrm{~g} / \mathrm{kg}$, which was recommended by the KDIGO 2020. Moreover, no studies proving the effectiveness of low-protein diets for type 2 diabetes have been cited. Type 2 diabetes accounts for approximately $90 \%$ of all diabetes cases. Hence, studies cited in the KDIGO 2020 cannot be used as a rationale for recommending low-protein diets, regardless of whether the recommended amount of intake is $0.8 \mathrm{~g} / \mathrm{kg}$ or $0.6 \mathrm{~g} / \mathrm{kg}$.

Table 4. Abstracts of two studies from the KDIGO 2020 that evaluated all-cause mortality.

\begin{tabular}{|c|c|c|c|c|c|c|}
\hline $\begin{array}{c}\text { First Author } \\
\text { (Year Published) }\end{array}$ & $\begin{array}{l}\text { Reference } \\
\text { Number }\end{array}$ & Patients & Intervention & Comparison & Mortality & Cause of Death \\
\hline $\begin{array}{l}\text { Hansen } \\
(2002)\end{array}$ & [39] & $\begin{array}{c}\text { T1DM, AER } \\
>300 \mathrm{mg} / \text { day, } \\
\text { eGFR } 68 \pm 31 \\
\mathrm{~mL} / \mathrm{min} / 1.73 \mathrm{~m}^{2} \\
n=82\end{array}$ & $0.6 \mathrm{~g} / \mathrm{kg}$ & Usual protein & 2/41 vs. $7 / 41$ & $\begin{array}{c}\text { Heart failure, 4; } \\
\text { myocardial } \\
\text { infarction, } 5\end{array}$ \\
\hline $\begin{array}{l}\text { Koya } \\
(2009)\end{array}$ & [40] & $\begin{array}{c}\text { T2DM, proteinuria } \\
>1 \mathrm{~g} / \text { day } \\
\text { eGFR } 62.3 \pm 25.3 \\
\mathrm{~mL} / \mathrm{min} / 1.73 \mathrm{~m}^{2} \\
n=112\end{array}$ & $0.8 \mathrm{~g} / \mathrm{kg}$ & $1.2 \mathrm{~g} / \mathrm{kg}$ & $\begin{array}{c}\text { n.s. } \\
1 / 56 \text { vs. } 1 / 56\end{array}$ & $\begin{array}{c}\text { Sepsis, } 1 ; \\
\text { myocardial } \\
\text { infarction, } 1\end{array}$ \\
\hline
\end{tabular}

TIDM, type 1 diabetes mellitus; T2DM, type 2 diabetes mellitus; eGFR, estimated glomerular filtration rate; AER, albumin excretion rate; KDIGO, Kidney Disease: Improving Global Outcomes. n.s., not significant. $\bigcirc$ indicates that intervention was statistically superior to control. 
Table 5. Abstracts of nine studies from the KDIGO 2020 that evaluated the renal protective effect of protein restriction.

\begin{tabular}{|c|c|c|c|c|c|c|c|}
\hline $\begin{array}{l}\text { First Author } \\
\text { (Year } \\
\text { Published) }\end{array}$ & $\begin{array}{l}\text { Reference } \\
\text { Number }\end{array}$ & Patients & Intervention & Comparison & $\begin{array}{l}\text { GFR Decline } \\
\text { per Year in I }\end{array}$ & $\begin{array}{l}\text { GFR Decline } \\
\text { per Year in C }\end{array}$ & $\begin{array}{c}\text { Statistical } \\
\text { Significance between } \\
\text { Groups }\end{array}$ \\
\hline $\begin{array}{l}\text { Zeller } \\
(1991)\end{array}$ & [41] & $\begin{array}{c}\text { T1DM, proteinuria > } 500 \\
\mathrm{mg} / \text { day, } \\
\mathrm{eGFR} 47.4 \pm 5.8 \mathrm{~mL} / \mathrm{min} / \\
1.73 \mathrm{~m}^{2} \\
n=35\end{array}$ & $0.6 \mathrm{~g} / \mathrm{kg}$ & Usual protein & -3.0 & -12.7 & 0 \\
\hline $\begin{array}{l}\text { Brouhard } \\
\text { (1990) }\end{array}$ & [42] & $\begin{array}{c}\text { T1DM, albuminuria } \\
>43.2 \mathrm{mg} / \text { day, } \\
\text { eGFR } \\
81.1 \pm 31.5 \mathrm{~mL} / \mathrm{min} / \\
1.73 \mathrm{~m}^{2} \\
n=15\end{array}$ & $0.6 \mathrm{~g} / \mathrm{kg}$ & Usual protein & -18 & -25 & 0 \\
\hline $\begin{array}{c}\text { Ciavarella } \\
\text { (1987) }\end{array}$ & [43] & $\begin{array}{c}\text { T1DM, } \\
\text { Proteinuria } \\
>500 \mathrm{mg} / \text { day, CCr } \\
100.6 \pm 29.6 \mathrm{~mL} / \mathrm{min} \\
n=16\end{array}$ & $0.71 \pm 0.12 \mathrm{~g} / \mathrm{kg}$ & $\begin{array}{l}\text { Normal protein } \\
(1.44 \pm 0.12 \mathrm{~g} / \mathrm{kg})\end{array}$ & 39.6 & -10.8 & n.s. \\
\hline $\begin{array}{l}\text { Dullaart } \\
(1993)\end{array}$ & [44] & $\begin{array}{c}\text { T1DM without DKD, } \\
\text { proteinuria } \\
<500 \mathrm{mg} / \text { day, GFR > } \\
90 \mathrm{~mL} / \mathrm{min} / 1.73 \mathrm{~m}^{2} \\
n=30\end{array}$ & $0.79 \pm 0.16 \mathrm{~g} / \mathrm{kg}$ & Usual protein & -9 & -5 & $\begin{array}{l}\text { n.s. (both groups } \\
\text { showed significant } \\
\text { reduction within } \\
\text { group) }\end{array}$ \\
\hline $\begin{array}{l}\text { Dussol } \\
\text { (2005) }\end{array}$ & [45] & $\begin{array}{c}\text { T1DM and T2DM, } \\
\text { Micro- or } \\
\text { macroalbuminuria, } \\
\text { GFR } 80 \pm 20 \mathrm{~mL} / \mathrm{min} / \\
1.73 \mathrm{~m}^{2} \\
n=47 \text { (T1DM, } 10 ; \mathrm{T} 2 \mathrm{DM} \\
37)\end{array}$ & $0.8 \mathrm{~g} / \mathrm{kg}$ & Usual protein & -3.5 & -2.5 & n.s. \\
\hline $\begin{array}{l}\text { Hansen } \\
(2002)\end{array}$ & [39] & $\begin{array}{c}\text { T1DM, Albuminuria > } \\
300 \mathrm{mg} / \text { day } \\
\text { eGFR } 68 \pm 31 \mathrm{~mL} / \mathrm{min} / \\
1.73 \mathrm{~m}^{2} \\
n=82\end{array}$ & $0.6 \mathrm{~g} / \mathrm{kg}$ & Usual protein & -3.8 & -3.9 & n.s. \\
\hline $\begin{array}{l}\text { Meloni } \\
(2002)\end{array}$ & [46] & $\begin{array}{c}\text { T1DM and T2DM, } \\
\text { Nephropathy and HT, } \\
\text { GFR } 44.8 \pm 5.7 \mathrm{~mL} / \mathrm{min} / \\
1.73 \mathrm{~m}^{2}, \\
n=69 \text { (T1DM, 32; T2DM, } \\
37 \text { ) }\end{array}$ & $0.6 \mathrm{~g} / \mathrm{kg}$ & Usual protein & -6.15 & -6.26 & n.s. \\
\hline $\begin{array}{c}\text { Raal } \\
(1994)\end{array}$ & [47] & $\begin{array}{c}\text { T1DM, proteinuria } \\
\text { dipstick positive, } \\
\text { GFR } 58 \pm 23 \mathrm{~mL} / \mathrm{min} / \\
1.73 \mathrm{~m}^{2} \\
n=22\end{array}$ & $0.8 \mathrm{~g} / \mathrm{kg}$ & $>1.6 \mathrm{~g} / \mathrm{kg}$ & 6 & -16 & n.a. \\
\hline
\end{tabular}

Ccr, creatinine clearance; TIDM, type 1 diabetes mellitus; T2DM, type 2 diabetes mellitus; eGFR, estimated glomerular filtration rate; DKD, diabetic kidney disease; KDIGO, Kidney Disease: Improving Global Outcomes, HT; hypertension, n.s.; not significant, n.a.; not available. $\bigcirc$ indicates that intervention was statistically superior to control.

\subsection{Reviewing Randomized Clinical Trial Meta-Analyses}

A meta-analysis provides the benefit of having a higher statistical power and a more robust point estimate than any individual study. Hence, the author searched PubMed using the following keywords: "diabetic kidney disease," "protein restriction," "randomized controlled trial," and "meta-analysis" (search equation is shown in the Appendix A). This search resulted in nine articles [49-57], from which the following were excluded: (1) one that only reported on non-diabetic CKD [50], and (2) another without a metaanalysis [51]. The results of the remaining seven meta-analyses are presented in Table 6 . Among the seven studies, three stated that low-protein diets were statistically significantly effective in slowing eGFR decrease $[49,54,57]$. Of these three studies, two reported statistical heterogeneity. Extremely high heterogeneity was observed in studies by Nezu et al. [54] and Li et al. [57], with $\mathrm{I}^{2}$ values of $92 \%$ and $89 \%$, respectively. Generally, it is not determined whether overall effectiveness is observed when there is high heterogeneity $\left(\mathrm{I}^{2}>75 \%\right)$. Thus, it is recommended that subgroup analysis be performed to examine the groups effectiveness if high heterogeneity is observed. Nezu et al. [54] stated that effectiveness was observed in groups with high compliance. If so, it is necessary for researchers to develop a method of low-protein diet education to help patients maintain a high level of compliance. In fact, the meta-analysis by Nezu et al. [54] included four randomized comparative studies 
that indicated the eGFR preservation effects of low-protein diets (studies reporting a shift toward favoring low-protein diets without overlapping the vertical line, indicating a mean difference of 0 in their forest plot). From these four studies, three $[41,43,47]$ examined patients with type 1 diabetes in whom the rates of eGFR decrease were extremely high among those in the control groups (annual rates were as follows: $-12.7 \mathrm{~mL} / \mathrm{min} / 1.73 \mathrm{~m}^{2}$ relative to a baseline eGFR of $47.4 \pm 5.8 \mathrm{~mL} / \mathrm{min} / 1.73 \mathrm{~m}^{2}$ [41]; $-25 \mathrm{~mL} / \mathrm{min} / 1.73 \mathrm{~m}^{2}$ relative to a baseline Ccr of $100.6 \pm 29.6 \mathrm{~mL} / \mathrm{min}$ [43]; and $-16 \mathrm{~mL} / \mathrm{min} / 1.73 \mathrm{~m}^{2}$ relative to a baseline GFR of $58 \mathrm{~mL} / \mathrm{min} / 1.73 \mathrm{~m}^{2}$ [47]). The remaining randomized comparative study of patients with type 2 diabetes [58] found that the GFR in patients with type 2 diabetes and macroalbuminuria who received normal-protein diets decreased from a baseline of $74.4 \pm 31.4 \mathrm{~mL} / \mathrm{min} / 1.73 \mathrm{~m}^{2}$ to $65.1 \pm 25.5 \mathrm{~mL} / \mathrm{min} / 1.73 \mathrm{~m}^{2}$ in four months. This can be translated to an extremely fast annual decrease of $27.9 \mathrm{~mL} / \mathrm{min} / 1.73 \mathrm{~m}^{2}$. It is surprising that the GFR in the low-protein diet group increased from a baseline of $56.3 \pm 29.0 \mathrm{~mL} / \mathrm{min} / 1.73 \mathrm{~m}^{2}$ to $74.2 \pm 40.4 \mathrm{~mL} / \mathrm{min} / 1.73 \mathrm{~m}^{2}$ in four months [58]. These changes indicated that low-protein diets led to hyperfiltration. In addition, Li et al. [57] stated that a dietary protein intake of $<0.8 \mathrm{~g} / \mathrm{kg}$ was highly effective. However, this statement corresponded with only two studies [41,43]. As mentioned above, the two studies examined patients with type 1 diabetes, and the rates of eGFR decrease were extremely high in the control groups, as did those in the study of Nezu et al. [41,43,54]. The effectiveness of low-protein diets with a protein intake of $0.8 \mathrm{~g} / \mathrm{kg}$, recommended by the KDIGO 2020, could not be verified. Moreover, the hyperfiltration theory was completely rejected based on these data.

Among the seven studies, four stated that low-protein diets were statistically significantly effective in reducing proteinuria or the albumin excretion rate $[49,53,56,57]$. Of these, two studies that reported heterogeneity revealed extremely high heterogeneity $(87.0 \%$ [56] and $90.0 \%$ [57]). That is, low-protein diets have not been proven to have unequivocal effects on reducing proteinuria or the albumin excretion rate. 
Table 6. List of meta-analyses of randomized protein restriction studies for diabetic kidney disease.

\begin{tabular}{|c|c|c|c|c|c|c|c|c|}
\hline \multirow{2}{*}{$\begin{array}{c}\text { First Author } \\
\text { (Year Published) }\end{array}$} & \multirow{2}{*}{$\begin{array}{l}\text { Reference } \\
\text { Number }\end{array}$} & \multirow{2}{*}{ Trial Number } & \multirow{2}{*}{ Type of Diabetes } & \multicolumn{2}{|l|}{ eGFR Decline } & \multicolumn{2}{|c|}{ Proteinuria or the Albumin Excretion Rate } & \multirow{2}{*}{$\begin{array}{c}\text { Conclusion of the } \\
\text { Paper }\end{array}$} \\
\hline & & & & Results & Heterogeneity & Results & Heterogeneity & \\
\hline $\begin{array}{l}\text { Pedrini } \\
(1996)\end{array}$ & [49] & $\begin{array}{l}5 \text { (including } 2 \\
\text { non-randomized study) }\end{array}$ & $\begin{array}{c}\text { T1DM, } n=3 \\
\text { T2DM, } n=0 \\
\text { Mix, } n=0 \\
\text { Total } n=3\end{array}$ & Significant reduction, $R R=0.56$ & n.a. & Significant reduction, $R R=0.56$ & n.a. & $\begin{array}{l}\text { Protein restriction } \\
\text { is effective for } \\
\text { slowing the } \\
\text { progression of } \\
\text { DKD }\end{array}$ \\
\hline $\begin{array}{l}\text { Robertson } \\
\quad(2007)\end{array}$ & [52] & $\begin{array}{c}12 \text { (including } 3 \\
\text { non-randomized study) }\end{array}$ & $\begin{array}{l}\text { T1DM } n=7 \\
\text { T2DM } n=2, \\
\text { Mix } n=0 \\
\text { Total } n=9\end{array}$ & $\begin{array}{l}\text { n.s. } \\
\text { n.s. } \\
\text { n.s. } \\
\text { n.s. }\end{array}$ & not applicable & Not reported & Not reoprted & $\begin{array}{l}\text { Protein restriction } \\
\text { appears to slightly } \\
\text { slow the } \\
\text { progression of } \\
\text { DKD }\end{array}$ \\
\hline $\begin{array}{l}\text { Pan } \\
(2008)\end{array}$ & [53] & 8 & $\begin{array}{c}\operatorname{T1DM} n=4 \\
\text { T2DM } n=2, \\
\text { Mix } n=2, \\
\text { Total } n=8\end{array}$ & $\begin{array}{l}\text { n.s. } \\
\text { n.s. } \\
\text { n.s. } \\
\text { n.s. }\end{array}$ & not applicable & $\begin{array}{c}\text { n.a. } \\
\text { n.a. } \\
\text { n.a. } \\
\text { significant reduction (SMD } \\
-0.69)\end{array}$ & n.a. & $\begin{array}{l}\text { Protein restriction } \\
\text { is not associated } \\
\text { with improvement } \\
\text { of renal function }\end{array}$ \\
\hline $\begin{array}{l}\text { Nezu } \\
(2013)\end{array}$ & [54] & 13 & $\begin{array}{c}\text { T1DM } n=6 \\
\text { T2DM } n=5 \\
\text { Mix } n=2 \\
\text { Total } n=13\end{array}$ & $\begin{array}{c}\text { n.s. } \\
\text { n.s. } \\
\text { n.s. } \\
\text { significant improvement } \\
5.82 \mathrm{~mL} / \mathrm{min} / 1.73 \mathrm{~m}^{2}\end{array}$ & $\mathrm{I}^{2}=92 \%$ & 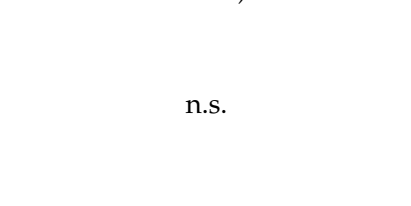 & not applicable & $\begin{array}{c}\text { Protein restriction } \\
\text { is significantly } \\
\text { associated with } \\
\text { improvement of } \\
\text { diabetic } \\
\text { nephropathy }\end{array}$ \\
\hline $\begin{array}{l}\text { Zhu } \\
(2018)\end{array}$ & [55] & 11 & $\begin{array}{c}\text { T1DM } n=5, \\
\text { T2DM } n=4, \\
\text { Mix } n=2, \\
\text { Total } n=11\end{array}$ & $\begin{array}{l}\text { n.s. } \\
\text { n.s. } \\
\text { n.s. } \\
\text { n.s. }\end{array}$ & not applicable & n.s. & not applicable & $\begin{array}{l}\text { Protein restriction } \\
\text { is not significantly } \\
\text { associated with } \\
\text { improvement of } \\
\text { renal function }\end{array}$ \\
\hline $\begin{array}{c}\mathrm{Li} \\
(2019)\end{array}$ & [56] & $\begin{array}{c}20 \text { (including } 11 \text { for eGFR } \\
\text { evaluation) }\end{array}$ & $\begin{array}{c}\text { T1DM } n=5 \\
\text { T2DM } n=5 \\
\text { Mix } n=1 \\
\text { Total } n=11\end{array}$ & $\begin{array}{l}\text { n.a. } \\
\text { n.a. } \\
\text { n.a. } \\
\text { n.s. }\end{array}$ & not applicable & $\begin{array}{c}\text { n.a. } \\
\text { n.a. } \\
\text { n.a. } \\
\text { significant reduction (SMD } \\
-0.62)\end{array}$ & $\mathrm{I}^{2}=87.0 \%$ & $\begin{array}{l}\text { No statistical } \\
\text { difference was } \\
\text { found in GFR } \\
\text { between the two } \\
\text { groups. }\end{array}$ \\
\hline $\begin{array}{c}\mathrm{Li} \\
(2020)\end{array}$ & [57] & 9 & $\begin{array}{c}\text { T1DM } n=5 \\
\text { T2DM } n=2, \\
\text { Mix } n=2 \\
\text { Total } n=9\end{array}$ & $\begin{array}{c}\text { n.a. } \\
\text { n.a. } \\
\text { n.a. } \\
\text { significant improvement } \\
3.86 \mathrm{~mL} / \mathrm{min} / 1.73 \mathrm{~m}^{2}\end{array}$ & $\mathrm{I}^{2}=89 \%$ & $\begin{array}{c}\text { n.a. } \\
\text { n.a. } \\
\text { n.a. } \\
\text { significant reduction (SMD } \\
-0.88)\end{array}$ & $\mathrm{I}^{2}=90.0 \%$ & $\begin{array}{c}\text { Dietary protein } \\
\text { intake of }< \\
0.8 \mathrm{~g} / \mathrm{kg} \text { was } \\
\text { strongly associated } \\
\text { with a slow decline } \\
\text { in eGFR. }\end{array}$ \\
\hline
\end{tabular}

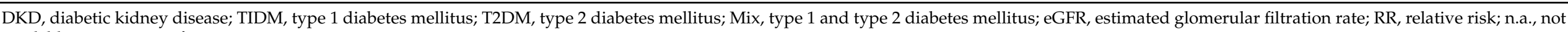
available; n.s., not significant. 


\subsection{Considering the Safety of Low-Protein Diets}

With the exclusion of studies consisting solely of rapid decliners, none of the abovementioned studies indicated the renal protective effects of low-protein diets. Moreover, Locatelli et al. [14] and Valazquez et al. [58] reported that the hyperfiltration theory was not valid in terms of protein intake. Several studies may indicate statistically significant differences. However, it is clear from a clinical perspective that the effectiveness of lowprotein diets remains unproven. In fact, a case report found that patient education on low-carbohydrate and high-protein diets (a carbohydrate intake of 80-90 g/day with protein accounting for $30 \%$ of the total energy intake) helped protect renal function [59]. Furthermore, one randomized controlled study reported that a low-carbohydrate, highprotein diet with low-iron and polyphenol-rich foods improved renal and overall survival than a low-protein diet [60]. The author and my colleague have also previously reported that patient education on low-carbohydrate diet (with an average protein intake of $1.6 \mathrm{~g} / \mathrm{kg}$ ) helped maintain the rate of decrease in the eGFR at $2.3 \mathrm{~mL} / \mathrm{min} / 1.73 \mathrm{~m}^{2}$ over the course of three years (a decrease of $0.8 \mathrm{~mL} / \mathrm{min} / 1.73 \mathrm{~m}^{2}$ annually), which was equivalent to that in healthy adults [61]. Thus, clinicians should always take into consideration the overall renal status of patients prior to recommending diet restrictions without rigorous clinical validation. Additionally, it is surprising that Kalantar-Zadeh et al.'s study [1] and the KDIGO 2020 still recommend low-protein diets. Given that such diets are recommended before their effectiveness is thoroughly validated, it can be assumed that their safety has barely been validated.

In terms of low-protein diet safety, the KDIGO 2020 mentioned a critical issue. That is, the World Health Organization (WHO) recommended a daily protein intake of $0.8 \mathrm{~g} / \mathrm{kg}$ for healthy people. The KDIGO's recommendation was based on the WHO's recommendation for protein intake for the general population. The WHO Technical Report 2007 [18] indicated a safe lower limit of protein intake at $0.83 \mathrm{~g} / \mathrm{kg}$, which was considered to satisfy the required amount of protein in $97.5 \%$ of a given group. It should be noted that the report did not recommend a protein intake of $0.8 \mathrm{~g} / \mathrm{kg}$. Indeed, a safe lower limit that satisfies the required amount in $97.5 \%$ of a given group is referred to as the "recommended dietary allowance (RDA)." However, the RDA should never be confused with the optimal recommended amount. The RDA indicates the minimum amount that limits the risk of deficiency. Hence, the author is wary of the possibility that the authors of the KDIGO 2020 were confused between the RDA and recommended amounts. Meanwhile, the WHO Technical Report did not mention any definitive figures for the safe upper limit. However, it is certainly safe to consume up to $1.66 \mathrm{~g} / \mathrm{kg}$ of protein, which is twice the RDA amount. The report stated that caution was required with amounts 3-4 times greater than the RDA $(2.49-3.32 \mathrm{~g} / \mathrm{kg})$, as it is not guaranteed that such amounts do not cause harm to health [18]. The KDIGO 2020 recommended that a protein intake of $0.8 \mathrm{~g} / \mathrm{kg}$ be maintained for DKD patients. However, given that the KDIGO 2020 drew on recommendations by the WHO, it should assure the safety for a protein intake of up to $1.66 \mathrm{~g} / \mathrm{kg}$ even for DKD patients. In addition, Kalantar-Zadeh et al. [1] recommended low-protein diets with a protein intake of $<1.0 \mathrm{~g} / \mathrm{kg}$ for diabetic patients without CKD. They also recommended a protein intake of $0.6-0.8 \mathrm{~g} / \mathrm{kg}$ for those with an eGFR of $<45 \mathrm{~mL} / \mathrm{min} / 1.73 \mathrm{~m}^{2}$. Rather, Kalantar-Zadeh et al. [1] should indicate that the RDA for a group with an eGFR of $<45 \mathrm{~mL} / \mathrm{min} / 1.73 \mathrm{~m}^{2}$ is not $0.83 \mathrm{~g} / \mathrm{kg}$ but $0.6 \mathrm{~g} / \mathrm{kg}$. The RDA refers to the minimum amount that helps a given group to avoid the risk of deficiency. Recommending low-protein diets without indicating that the RDA is reduced to $0.6 \mathrm{~g} / \mathrm{kg}$ imposes a risk on patients. Furthermore, the benefits of low-protein diets and the protection of renal function by such diets were not assured. Certain researchers claimed the effectiveness of limiting phosphate loads through low-protein diets [62]. In contrast, Shinaberger et al. [63] warned against recommending low-protein diets that are aimed at reducing phosphate loads by suggesting that low-protein diets lead to increased mortality despite phosphate intake reduction [63]. Particularly, clinicians should be reminded that extremely low-protein diets may increase the risk of mortality $[62,64]$. 
Furthermore, Robertson et al. [52] reported that there was no data on the effects of low-protein diet on health-related quality of life and costs. Further study evaluating qualityadjusted life-years associated with low-protein diet is required prior to its recommendation.

\section{Conclusions}

The renal protective effects of low-protein diets are still unclear in diabetic patients with CKD. Moreover, some studies have reported that extremely low-protein diets may increase the risk of mortality. Thus, the author discourages the recommendation of lowprotein diet to diabetic patients with CKD at any stage, until scientific evidence unequivocally proves its renal protective effects.

Those who recommend low-protein diets at levels less than the RDA may need to review their clinical practice by respecting the principle of medicine: "First, Do No Harm."

Funding: There is no funding for this paper.

Institutional Review Board Statement: The study was conducted according to the guidelines of the Declaration of Helsinki, and approved by the Institutional Review Board of Kitasato Institute Hospital (study number 20047 and date of approval is 6 October 2020).

Informed Consent Statement: This is a review article in which patient consent is not applicable.

Conflicts of Interest: The author declares no conflict of interest.

\section{Appendix A}

31 December 2020: ("diabetic kidney disease" [All Fields] OR "diabetic nephropathy" [All Fields]) AND ("protein restriction" [All Fields] OR "low protein" [All Fields]) AND ("random allocation" [MeSH Terms] OR ("random" [All Fields] AND "allocation" [All Fields]) OR "random allocation" [All Fields] OR "random" [All Fields] OR "randomization" [All Fields] OR "randomized" [All Fields] OR "randomisation" [All Fields] OR "randomisations" [All Fields] OR "randomise" [All Fields] OR "randomised" [All Fields] OR "randomising" [All Fields] OR "randomizations" [All Fields] OR "randomize" [All Fields] OR "randomizes" [All Fields] OR "randomizing" [All Fields] OR "randomness" [All Fields] OR "randoms" [All Fields] OR ("random allocation" [MeSH Terms] OR ("random" [All Fields] AND "allocation" [All Fields]) OR "random allocation" [All Fields] OR "random" [All Fields] OR "randomization" [All Fields] OR "randomized" [All Fields] OR "randomisation" [All Fields] OR "randomisations" [All Fields] OR "randomise" [All Fields] OR "randomised" [All Fields] OR "randomising" [All Fields] OR "randomizations" [All Fields] OR "randomize" [All Fields] OR "randomizes" [All Fields] OR "randomizing" [All Fields] OR "randomness" [All Fields] OR "randoms" [All Fields])) AND ("meta analysis") [Publication Type] OR "meta analysis as topic" [MeSH Terms] OR "meta analysis" [All Fields].

\section{References}

1. Kalantar-Zadeh, K.; Fouque, D. Nutritional management of chronic kidney disease. N. Engl. J. Med. 2017, 377, 1765-1776. [CrossRef] [PubMed]

2. Kidney Disease: Improving Global Outcomes (KDIGO) Diabetes Work Group. KDIGO 2020 Clinical practice guideline for diabetes management in chronic kidney disease. Kidney Int. 2020, 98, S1-S115. [CrossRef] [PubMed]

3. Bantle, J.P.; Wylie-Rosett, J.; Albright, A.L.; Apovian, C.M.; Clark, N.G.; Franz, M.J.; Hoogwerf, B.J.; Lichtenstein, A.H.; MayerDavis, E.; Mooradian, A.D.; et al. Nutrition recommendations and interventions for diabetes: A position statement of the American Diabetes Association. Diabetes Care 2008, 31 (Suppl. 1), S61-S78.

4. $\quad$ Evert, A.B.; Boucher, J.L.; Cypress, M.; Dunbar, S.A.; Franz, M.J.; Mayer-Davis, E.J.; Neumiller, J.J.; Nwankwo, R.; Verdi, C.L.; Urbanski, P.; et al. Nutrition therapy recommendations for the management of adults with diabetes. Diabetes Care 2013, 36, 3821-3842. [CrossRef]

5. $\quad$ Evert, A.B.; Dennison, M.; Gardner, C.D.; Garvey, W.T.; Lau, K.H.K.; MacLeod, J.; Mitri, J.; Pereira, R.F.; Rawlings, K.; Robinson, S.; et al. Nutrition therapy for adults with diabetes or prediabetes: A consensus report. Diabetes Care 2019, 42, 731-754. [CrossRef] [PubMed]

6. Addis, T. Glomerular Nephritis: Diagnosis and Treatment; Macmillan: New York, NY, USA, 1948. 
7. Brenner, B.M.; Meyer, T.W.; Hostetter, T.H. Dietary protein intake and the progressive nature of kidney disease: The role of hemodynamically mediated glomerular injury in the pathogenesis of progressive glomerular sclerosis in aging, renal ablation, and intrinsic renal disease. N. Engl. J. Med. 1982, 307, 652-659.

8. Brenner, B.M.; Lawler, E.V.; Mackenzie, H.S. The hyperfiltration theory: A paradigm shift in nephrology. Kidney Int. 1996, 49, 1774-1777. [CrossRef]

9. Wanner, C.; Inzucchi, S.E.; Lachin, J.M.; Fitchett, D.; von Eynatten, M.; Mattheus, M.; Biomath, D.; Johansen, O.E.; Woerle, H.J.; Broedl, U.C.; et al. Empagliflozin and progression of kidney disease in type 2 diabetes. N. Engl. J. Med. 2016, 375, 323-334. [CrossRef]

10. Pekovic, V.; Jardine, M.J.; Neal, B.; Bompoint, S.; Heerspink, H.J.L.; Charytan, D.M.; Edwards, R.; Agarwal, R.; Bakris, G.; Bull, S.; et al. Canagliflozin and renal outcomes in type 2 diabetes and nephropathy. N. Engl. J. Med. 2019, 380, 2295-2306. [CrossRef]

11. Heerspink, H.J.L.; Stefansson, B.V.; Correa-Rotter, R.; Chertow, G.M.; Greene, T.; Hou, F.F.; Mann, J.F.E.; McMurray, J.J.V.; Lindberg, M.; Rossing, P.; et al. Dapagliflozin in patients with chronic kidney disease. N. Engl. J. Med. 2020, 383, 1436-1446. [CrossRef]

12. Mazzucato, M.; Fioretto, P.; Avogaro, A. High-protein diet: A barrier to the nephroprotective effects of sodium-glucose cotransporter-2 inhibitors? Diabetes Obes Metab 2020, 22, 1511-1515. [CrossRef]

13. Klahr, S.; Levey, A.S.; Beck, G.J.; Gaggiula, A.W.; Hunsicker, L.; Kusek, J.W.; Striker, G. The effects of dietary protein restriction and blood-pressure control on the progression of chronic renal disease. N. Engl. J. Med. 1994, 330, 877-884. [CrossRef]

14. Locatelli, F.; Alberti, D.; Graziani, G.; Buccianti, G.; Redaelli, B.; Giangrande, A. Prospective, randomised, multicentre trial of effect of protein restriction on progression of chronic renal insufficiency. Lancet 1991, 337, 1299-1304. [CrossRef]

15. Levey, A.S.; Greene, T.; Sarnak, M.J.; Wang, X.; Beck, G.J.; Kusek, J.W.; Collins, A.J.; Kopple, J.D. Effect of dietary protein restriction on the progression of kidney disease: Long-term follow-up of the Modification of diet in renal disease (MDRD) study. Am. J. Kidney Dis. 2006, 48, 879-888. [CrossRef]

16. León-Jiménez, D.; López-Mendoza, M.; Pérez-Temprano, R.; Górriz, J.L.; Miramontes-González, J.P. In response to the paper 'High-protein diet: A barrier to the nephroprotective effects of sodium-glucose co-transporter-2 inhibitors?'. Diabetes Obes. Metab. 2020, 22, 1701-1702. [CrossRef]

17. Hostetter, T.H.; Meyer, T.W.; Rennke, H.G.; Brenner, B.M. Chronic effects of dietary protein in the rat with intact and reduced renal mass. Kidney Int. 1986, 30, 509-517. [CrossRef]

18. Joint FAO/WHO/UNU. Expert Consultation on Protein and Amino Acid Requirements in Human Nutrition. Protein and Amino Acid Requirements in Human Nutrition; Report of a Joint FAO/WHO/UNU Expert Consultation; World Health Organization Technical Report Series; World Health Organization: Geneva, Switzerland, 2007.

19. Lambert, C.P.; Frank, L.L.; Evans, W.J. Macronutrient considerations for the sport of bodybuilding. Sports Med. 2004, 34, 317-327. [CrossRef]

20. Rosman, J.B.; ter Wee, P.M.; Meijer, S.; Piers-Becht, T.P.; Sluiter, W.J.; Donker, A.J. Prospective randomised trial of early dietary protein restriction in chronic renal failure. Lancet 1984, 2, 1291-1296. [CrossRef]

21. Rosman, J.B.; Langer, K.; Brandl, M.; Piers-Becht, T.P.; van der Hem, G.K.; ter Wee, P.M.; Donker, A.J. Protein-restricted diets in chronic renal failure: A four year follow-up shows limited indications. Kidney Int. Suppl. 1989, 27, S96-S102. [PubMed]

22. Ihle, B.U.; Becker, G.J.; Whitworth, J.A.; Charlwood, R.A.; Kincaid-Smith, P.S. The effect of protein restriction on the progression of renal insufficiency. N. Engl. J. Med. 1989, 321, 1773-1777. [CrossRef] [PubMed]

23. Lindenau, K.; Abendroth, K.; Kokot, F.; Vetter, K.; Rehse, C.; Fröhling, P.T. Therapeutic effect of keto acids on renal osteodystrophy. A prospective controlled study. Nephron 1990, 55, 133-135. [CrossRef]

24. Williams, P.S.; Stevens, M.E.; Fass, G.; Irons, L.; Bone, J.M. Failure of dietary protein and phosphate restriction to retard the rate of progression of chronic renal failure: A prospective, randomized, controlled trial. Q. J. Med. 1991, 81, 837-855. [CrossRef]

25. Montes-Delgado, R.; Guerrero Riscos, M.A.; García-Luna, P.P.; Martín Herrera, C.; Pereira Cunill, J.L.; Garrido Vázquez, M.; López Muñoz, I.; Suárez García, M.J.; Martín-Espejo, J.L.; Soler Junco, M.L. Tratamiento con dieta hipoproteica y suplementos calóricos en pacientes con insuficiencia renal crónica en prediálisis. Estudio comparativo [Treatment with low-protein diet and caloric supplements in patients with chronic kidney failure in predialysis. Comparative study]. Rev. Clin. Esp. 1998, 198, 580-586. (In Spanish) [PubMed]

26. Malvy, D.; Maingourd, C.; Pengloan, J.; Bagros, P.; Nivet, H. Effects of severe protein restriction with ketoanalogues in advanced renal failure. J. Am. Coll. Nutr. 1999, 18, 481-486. [CrossRef] [PubMed]

27. Teplan, V.; Schück, O.; Knotek, A.; Hajný, J.; Horácková, M.; Skibová, J.; Malý, J. Effects of low-protein diet supplemented with ketoacids and erythropoietin in chronic renal failure: A long-term metabolic study. Ann. Transplant. 2001, 6, 47-53. [PubMed]

28. Prakash, S.; Pande, D.P.; Sharma, S.; Sharma, D.; Bal, C.S.; Kulkarni, H. Randomized, double-blind, placebo-controlled trial to evaluate efficacy of ketodiet in predialytic chronic renal failure. J. Ren. Nutr. 2004, 14, 89-96. [CrossRef] [PubMed]

29. Brunori, G.; Viola, B.F.; Parrinello, G.; De Biase, V.; Como, G.; Franco, V.; Garibotto, G.; Zubani, R.; Cancarini, G.C. Efficacy and safety of a very-low-protein diet when postponing dialysis in the elderly: A prospective randomized multicenter controlled study. Am. J. Kidney Dis. 2007, 49, 569-580. [CrossRef] [PubMed]

30. Mircescu, G.; Gârneaţă, L.; Stancu, S.H.; Căpuşă, C. Effects of a supplemented hypoproteic diet in chronic kidney disease. J. Ren. Nutr. 2007, 17, 179-188. [CrossRef] 
31. Cianciaruso, B.; Pota, A.; Bellizzi, V.; Di Giuseppe, D.; Di Micco, L.; Minutolo, R.; Pisani, A.; Sabbatini, M.; Ravani, P. Effect of a low- versus moderate-protein diet on progression of CKD: Follow-up of a randomized controlled trial. Am. J. Kidney Dis. 2009, 54, 1052-1061. [CrossRef]

32. Di Iorio, B.R.; Cucciniello, E.; Martino, R.; Frallicciardi, A.; Tortoriello, R.; Struzziero, G. Acuto e persistente effetto antiproteinurico della dieta ipoproteica artificiale nella malattia renale cronica [Acute and persistent antiproteinuric effect of a low-protein diet in chronic kidney disease]. G. Ital. Nefrol. 2009, 26, 608-615. (In Italian)

33. Jiang, N.; Qian, J.; Sun, W.; Lin, A.; Cao, L.; Wang, Q.; Ni, Z.; Wan, Y.; Linholm, B.; Axelsson, J.; et al. Better preservation of residual renal function in peritoneal dialysis patients treated with a low-protein diet supplemented with keto acids: A prospective, randomized trial. Nephrol. Dial. Transplant. 2009, 24, 2551-2558. [CrossRef] [PubMed]

34. Jiang, N.; Qian, J.; Lin, A.; Fang, W.; Zhang, W.; Cao, L.; Wang, Q.; Ni, Z.; Yao, Q. Low-protein diet supplemented with keto acids is associated with suppression of small-solute peritoneal transport rate in peritoneal dialysis patients. Int. J. Nephrol. 2011, 2011, 542704. [CrossRef] [PubMed]

35. Garneata, L.; Stancu, A.; Dragomir, D.; Stefan, G.; Mircescu, G. Ketoanalogue-supplemented vegetarian very low-protein diet and CKD progression. J. Am. Soc. Nephrol. 2016, 27, 2164-2176. [CrossRef]

36. Coresh, J.; Turin, T.C.; Matsushita, K.; Sang, Y.; Ballew, S.H.; Appel, L.J.; Arima, H.; Chadban, S.J.; Cirillo, M.; Djurdjev, O. Decline in estimated glomerular filtration rate and subsequent risk of end-stage renal disease and mortality. JAMA 2014, 311, 2518-2531. [CrossRef]

37. Inker, L.A.; Heerspink, H.J.L.; Tighiouart, H.; Levey, A.S.; Coresh, J.; Gansevoort, R.T.; Simon, A.L.; Ying, J.; Beck, G.J.; Wanner, C. GFR slope as a surrogate end point for kidney disease progression in clinical trials: A meta-analysis of treatment effects of randomized controlled trials. J. Am. Soc. Nephrol. 2019, 30, 1735-1745. [CrossRef]

38. Stevens, P.E.; Levin, A. Evaluation and management of chronic kidney disease: Synopsis of the kidney disease: Improving global outcomes 2012 clinical practice guideline. Ann. Intern. Med. 2013, 158, 825-830. [CrossRef]

39. Hansen, H.P.; Tauber-Lassen, E.; Jensen, B.R.; Parving, H.H. Effect of protein restriction on prognosis in patients with diabetic nephropathy. Kidney Int. 2002, 62, 220-228. [CrossRef]

40. Koya, D.; Haneda, M.; Inomata, S.; Suzuki, Y.; Suzuki, D.; Makino, H.; Shikata, K.; Murakami, Y.; Tomino, Y.; Yamada, K.; et al. Long-term effect of modification of dietary protein intake on the progression of diabetic nephropathy: A randomised controlled trial. Diabetologia 2009, 52, 2037-2045. [CrossRef]

41. Zeller, K.; Whittaker, E.; Sullivan, L.; Raskin, P.; Jacobson, H.R. Effect of restricting dietary protein on the progression of renal failure in patients with insulin-dependent diabetes mellitus. N. Engl. J. Med. 1991, 324, 78-84. [CrossRef] [PubMed]

42. Brouhard, B.H.; LaGrone, L. Effect of dietary protein restriction on functional renal reserve in diabetic nephropathy. Am. J. Med. 1990, 89, 427-431. [CrossRef]

43. Ciavarella, A.; Di Mizio, G.; Stefoni, S.; Borgnino, L.C.; Vannini, P. Reduced albuminuria after dietary protein restriction in insulin-dependent diabetic patients with clinical nephropathy. Diabetes Care 1987, 10, 407-413. [CrossRef] [PubMed]

44. Dullaart, R.P.; Beusekamp, B.J.; Meijer, S.; van Doormaal, J.J.; Sluiter, W.J. Long-term effects of protein-restricted diet on albuminuria and renal function in IDDM patients without clinical nephropathy and hypertension. Diabetes Care 1993, 16, 483-492. [CrossRef] [PubMed]

45. Dussol, B.; Iovanna, C.; Raccah, D.; Darmon, P.; Morange, S.; Vague, P.; Vialettes, B.; Oliver, C.; Loundoun, A.; Berland, Y. A randomized trial of low-protein diet in type 1 and in type 2 diabetes mellitus patients with incipient and overt nephropathy. $J$. Ren. Nutr. 2005, 15, 398-406. [CrossRef] [PubMed]

46. Meloni, C.; Morosetti, M.; Suraci, C.; Pennafina, M.G.; Tozzo, C.; Taccone-Gallucci, M.; Casciani, C.U. Severe dietary protein restriction in overt diabetic nephropathy: Benefits or risks? J. Ren. Nutr. 2002, 12, 96-101. [CrossRef]

47. Raal, F.J.; Kalk, W.J.; Lawson, M.; Esser, J.D.; Buys, R.; Fourie, L.; Panz, V.R. Effect of moderate dietary protein restriction on the progression of overt diabetic nephropathy: A 6-mo prospective study. Am. J. Clin. Nutr. 1994, 60, 579-585. [CrossRef]

48. Colombo, M.; McGurnaghan, S.J.; Bell, S.; MacKenzie, F.; Patrick, A.W.; Petrie, J.R.; McKnight, J.A.; MacRury, S.; Traynor, J.; Metcalfe, W. Predicting renal disease progression in a large contemporary cohort with type 1 diabetes mellitus. Diabetologia 2020, 63, 636-647. [CrossRef] [PubMed]

49. Pedrini, M.T.; Levey, A.S.; Lau, J.; Chalmers, T.C.; Wang, P.H. The effect of dietary protein restriction on the progression of diabetic and nondiabetic renal diseases: A meta-analysis. Ann. Intern. Med. 1996, 124, 627-632. [CrossRef] [PubMed]

50. Fouque, D.; Wang, P.; Laville, M.; Boissel, J.P. Low protein diets delay end-stage renal disease in non-diabetic adults with chronic renal failure. Nephrol. Dial. Transplant. 2000, 15, 1986-1992. [CrossRef]

51. Zarazaga, A.; García-De-Lorenzo, L.; García-Luna, P.P.; García-Peris, P.; López-Martínez, J.; Lorenzo, V.; Quecedo, L.; Del Llano, J. Nutritional support in chronic renal failure: Systematic review. Clin. Nutr. 2001, 20, 291-299. [CrossRef]

52. Robertson, L.; Waugh, N.; Robertson, A. Protein restriction for diabetic renal disease. Cochrane Database Syst. Rev. 2007, 17, CD002181. [CrossRef]

53. Pan, Y.; Guo, L.L.; Jin, H.M. Low-protein diet for diabetic nephropathy: A meta-analysis of randomized controlled trials. Am. J. Clin. Nutr. 2008, 88, 660-666. [CrossRef] [PubMed]

54. Nezu, U.; Kamiyama, H.; Kondo, Y.; Sakuma, M.; Morimoto, T.; Ueda, S. Effect of low-protein diet on kidney function in diabetic nephropathy: Meta-analysis of randomised controlled trials. BMJ Open 2013, 3, e002934. [CrossRef] [PubMed] 
55. Zhu, H.G.; Jiang, Z.S.; Gong, P.Y.; Zhang, D.M.; Zou, Z.W.; Zhang, Q.; Ma, H.M.; Guo, Z.G.; Zhao, J.Y.; Dong, J.J.; et al. Efficacy of low-protein diet for diabetic nephropathy: A systematic review of randomized controlled trials. Lipids Health Dis. 2018, 17, 141. [CrossRef]

56. Li, X.F.; Xu, J.; Liu, L.J.; Wang, F.; He, S.L.; Su, Y.; Dong, C.P. Efficacy of low-protein diet in diabetic nephropathy: A meta-analysis of randomized controlled trials. Lipids Health Dis. 2019, 18, 82. [CrossRef] [PubMed]

57. Li, Q.; Wen, F.; Wang, Y.; Li, S.; Lin, S.; Qi, C.; Chen, Z.; Qiu, X.; Zhang, Y.; Zhang, S.; et al. Diabetic kidney disease benefits from intensive low-protein diet: Updated systematic review and meta-analysis. Diabetes Ther. 2020. [CrossRef] [PubMed]

58. Velázquez López, L.; Sil Acosta, M.J.; Goycochea Robles, M.V.; Torres Tamayo, M.; Castañeda Limones, R. Effect of protein restriction diet on renal function and metabolic control in patients with type 2 diabetes: A randomized clinical trial. Nutr. Hosp. 2008, 23, 141-147.

59. Nielsen, J.V.; Westerlund, P.; Bygren, P. A low-carbohydrate diet may prevent end-stage renal failure in type 2 diabetes. A case report. Nutr. Metab. 2006, 3, 23. [CrossRef]

60. Facchini, F.S.; Saylor, K.L. A low-iron-available, polyphenol-enriched, carbohydrate-restricted diet to slow progression of diabetic nephropathy. Diabetes 2003, 52, 1204-1209. [CrossRef]

61. Sanada, M.; Kabe, C.; Hata, H.; Uchida, J.; Inoue, G.; Tsukamoto, Y.; Yamada, Y.; Irie, J.; Tabata, S.; Tabata, M.; et al. Efficacy of a moderately low carbohydrate diet in a 36-month observational study of Japanese Patients with type 2 diabetes. Nutrients 2018, 10, 528. [CrossRef]

62. Menon, V.; Kopple, J.D.; Wang, X.; Beck, G.J.; Collins, A.J.; Kusek, J.W.; Greene, T.; Levey, A.S.; Sarnak, M.J. Effect of a very low-protein diet on outcomes: Long-term follow-up of the Modification of Diet in Renal Disease (MDRD) Study. Am. J. Kidney Dis. 2009, 53, 208-217. [CrossRef]

63. Shinaberger, C.S.; Greenland, S.; Kopple, J.D.; Van Wyck, D.; Mehrotra, R.; Kovesdy, C.P.; Kalantar-Zadeh, K. Is controlling phosphorus by decreasing dietary protein intake beneficial or harmful in persons with chronic kidney disease? Am. J. Clin. Nutr. 2008, 88, 1511-1518. [CrossRef] [PubMed]

64. Ikizler, T.A. Dietary protein restriction in CKD: The debate continues. Am. J. Kidney Dis. 2009, 53, 189-191. [CrossRef] [PubMed] 